\title{
The Motivations of Learning English for Specific Purposes (ESP) Courses: A Study of English for Nursing Purposes
}

\author{
Luis M. Dos Santos \\ Woosong Language Institute, Woosong University, South Korea \\ Received October 1, 2020; Revised November 19, 2020; Accepted December 6, 2020
}

\section{Cite This Paper in the following Citation Styles}

(a): [1] Luis M. Dos Santos, "The Motivations of Learning English for Specific Purposes (ESP) Courses: A Study of English for Nursing Purposes," Universal Journal of Educational Research, Vol. 8, No. 12A, pp. 7809-7817, 2020. DOI: 10.13189/ujer.2020.082569.

(b): Luis M. Dos Santos (2020). The Motivations of Learning English for Specific Purposes (ESP) Courses: A Study of English for Nursing Purposes. Universal Journal of Educational Research, 8(12A), 7809-7817. DOI: 10.13189/ujer.2020.082569.

Copyright $\mathrm{C} 2020$ by authors, all rights reserved. Authors agree that this article remains permanently open access under the terms of the Creative Commons Attribution License 4.0 International License

\begin{abstract}
English language learning is not uncommon for many university students and programmes, particularly in the fields of nursing education. Pre-service nursing students are required to take certain courses of English language courses in order to meet the educational requirement in many universities in South Korea. However, there is no regulation about what types of English courses should be offered. In this study, based on the information (i.e. inductive surveys, interview sessions, and focus group activities) from 64 currently enrolled nursing students, the researcher sought to understand two research questions, which were, After the completion of both English for Specific Purposes (ESP) (i.e. English for Nursing Purposes) courses and English for General Purposes (EGP), which course would you prefer? Why; and how would the English for Specific Purposes (ESP) (i.e. English for Nursing Purposes) courses meet your expectations as nursing students at the university-level? The results indicated that nursing students tend to select the English for Specific Purposes (ESP) courses for their English language development because the materials were designed to meet their occupational needs after university graduation (i.e. in the health facilities). The outcomes of this study provided a blueprint for school leaders and department heads to reform and polish their nursing curriculum and plan in order to answer the feedback of the students and pre-service nursing professionals.
\end{abstract}

Keywords English as a Foreign Language, English for General Purpose, English for Specific Purpose, Foreign Language Teaching, Nursing English, Teaching English to Speakers of Other Languages

\section{Introduction}

In the fields of English language teaching and learning, there are different strategies about how to provide appropriate English language courses to learners with different purposes, perspectives, and expectations [1]. In general, based on the literature, it is not uncommon to find postgraduate degree programmes in these areas, including but not limited to, English Language Teaching (ELT) [2], Teaching English to Speakers of Other Languages (TESOL) [3], Teaching English for Academic Purposes (TEAP) [4], Teaching English as a Foreign Language (TEFL) [5], Teaching English to Speakers of Other Languages for Young Learners (TESOLYL) [6], and Applied Linguistics [7]. However, there are no standardised curriculum and degree plans for each individual programme [8], [9]. In other words, based on the needs and designs of each individual degree programme, the university may import modules and courses, such as English for Specific Purposes (ESP), English for Academic Purposes (EAP), and English for General Purposes (EGP) into the curriculum and 
instruction for their degree-seeking students (i.e. pre-service English language teachers). However, most of these degree graduates (i.e. with trained teaching and learning experiences for English language learners) understood the developments and importance of the ideas of English for Specific Purposes (ESP) at the university-level. As university students usually have their own expectations, directions, and perspectives about their teaching and learning direction and curriculum based on their university major and degree, English language department, for example, should design the English for Specific Purposes (ESP) courses for individual programme(s) in order to meet the expectations of the learners [10].

With the focus of English for Specific Purpose (ESP), effective foreign language teaching and learning is vital in all academic and professional areas, particularly in the medical professions and nursing [11]-[13]. Some important elements should be considered for any curriculum and instructional development. Understanding and applying the appropriate teaching and learning strategies for undergraduate college and university students are the major purposes of this educational research.

As a result, from the perspectives of nursing students at the nursing school environments in South Korea, the current study has investigated the motivation of learning for English as a foreign language (EFL) with the direction of English for Nursing Purposes (ENP). The researcher collected a series of qualitative data (i.e. inductive surveys, individual interview sessions and focus group activities) from 64 nursing students who are currently studying nursing as their university major in South Korea [14], [15]. The results of this study may provide a blueprint for school leaders, department heads, policymakers, government officials, and researchers to reform and polish their foreign language policies and professional developments for both pre-service [18-19] and in-service medical professionals [16] in the East Asian region.

\subsection{Significance of the Study and Literature Review}

This study has four significant aspects. As a part of the literature review, the researcher reviewed some previous behaviours, teaching trends, and expectations in the East Asian region.

First, public health, social caring, and medical professionals mainly work in front-line services [18]. In other words, unless working in the back-office or in research institutions, public health, social caring, and medical professionals need to provide face-to-face services and treatment to their patients. Due to the nature of their work, these groups of professionals need to have higher-level communication and interpersonal skills and abilities in order to exchange and share information with their patients and other professionals. Therefore, higher-level native and foreign language skills are always needed [19]. A previous study [5] indicated that foreign language teaching and learning for medical professionals is vital as medical professionals always need to interact with non-native speakers in their home country. As an international practice, medical professionals should handle at least two languages in order to serve the larger population. Therefore, foreign language teachers need to identify and implement effective teaching and learning strategies for their students.

Second, due to their social and cultural tradition and background, most East Asian students, particularly Korean students, accepted the traditional teacher-centred teaching and learning strategy [20]-[22] and the top-down approach [23] in their classroom environments [24], including in foreign language courses. Although traditional teacher-centred teaching and learning strategies are effective in some classroom environments, identifying and employing alternative teaching and learning strategies can increase language learners' motivation and interest [25], [26]. A previous study [27] indicated that students tend to study in a shared-oriented classroom environment (i.e. flipped classroom and strategy) where each can express their feedback and opinion with their knowledge and understanding. For example, in the nursing classroom environments, students may bring their understanding, stories, experiences and feeling about the knowledge, textbook materials and previous experiences for peer lecturing. These teaching and learning strategies do not only increase the overall performance and experiences of the nursing students, but also the engagements between students and teachers [28].

Third, several studies indicated that most East Asian foreign language classroom environments tend to focus on the textbook-based teaching and learning approach [23], [29]. In other words, foreign language classrooms tend to use textbooks and related workbooks as the primary teaching and learning tools and materials [8], [30], [31]. Technologically-assisted teaching and learning materials and tools are not provided. Although some classrooms employ PowerPoint presentations and audio recordings as supplementary materials and tools, the main knowledge-transferring method remains the use of textbooks and workbooks.

Fourth, although there are many English for Specific Purposes (ESP) [32] and English for Academic Purposes (EAP) textbooks for public health, social caring, and medical students, most textbook materials and case studies are out-dated [33]. In other words, students usually cannot apply textbook-derived knowledge to their practices, workplace, and placement sites due to these materials and knowledge being theoretical-based. Although learners gain knowledge and language skills from the classroom, they usually cannot apply such skills in their future working environments. For example, a previous study [32] with the focus on the Korean textbook materials indicated 
that textbook evaluation is one of the key elements to locating the appropriate teaching and learning materials for nursing students. The study, however, did not explore the teaching and learning strategy. Although the department heads locate the appropriate textbook materials, teaching and learning strategies and methods should be evaluated and assessed in order to meet the expectations of the nursing students. Therefore, there is a need to expand the teaching and learning strategy for nursing students and educators [34], [35].

\subsection{Research Questions}

As the purposes of this study were to investigate the motivations of learning and the learning behaviours of nursing students in South Korea, the research study was guided by two research questions,

(1) After the completion of both English for Specific Purposes (ESP) (i.e. English for Nursing Purposes) courses and English for General Purposes (EGP), which course would you prefer? Why?

(2) How would the English for Specific Purposes (ESP) (i.e. English for Nursing Purposes) courses meet your expectations as nursing students at the university-level?

\section{Materials and Methods}

The employment of the qualitative research method [36] has been used in this study. The qualitative research method allows the researcher to collect first-hand and in-depth understanding, data, and sharing from the participants. The research could enter the understanding and the social world of the participants about the particular topic(s). Based on the nature and the design of the current study, the researcher decided to employ the General Inductive Approach [37] as the tool for investigation.

\subsection{Explanation between the English for General Purposes and English for Specific Purposes Materials}

In this study, the students are required to take at least four courses of English language courses in order to graduate. As a planned curriculum of the nursing department, during the first two academic terms, students should take two courses of English for General Purposes (EGP). After the completion of the first two English for General Purposes (EGP) courses, students then complete the second two English for Specific Courses (ESP) in the field of nursing English.

The English for General Purposes (EGP) courses mainly focus on general knowledge, grammar, lexical sets, and daily conversation. In other words, the syllabus and designs of these English for General Purposes (EGP) tend to increase the overall performance and daily exchanges of the students. No particular skills are focused on.

The English for Specific Purposes (ESP) courses in the field of nursing English mainly focus on the targeted sites, background, and application for health and medical staff in the hospitals and clinical environments. Depending on the teaching and learning materials (i.e. textbooks) and the instructors, the English for Specific Purposes (ESP) courses with the focus on nursing English tend to provide the skills in the areas of patient-medical staff conversation, skills in the hospitals and clinical environments, targeted vocabulary, and health promotion etc.

\subsection{Participants}

64 nursing students in South Korea (i.e. at two different universities) were invited for this study. All agreed to participate in this study. All the participants were undergraduate students who are seeking their initial license for nursing practice (i.e. undergraduate bachelor's degree). The researcher invited these participants based on the purposive sampling strategy [14]. In other words, the researcher invited a group of nursing students based on his own network and personal connection at a university. The participants needed to meet the following criteria, which were:

(1) Seeking an undergraduate degree in the major of nursing in South Korea;

(2) Completing at least one course in English for General Purposes (EGP) and English for Specific Purposes (ESP) at the university-level.

\subsection{Data Collection}

Three types of data collection tools and ways were employed in this study (i.e. inductive surveys, individual interviews, and focus group activities). All tools were exercised to understand and seek the information and share about their perspectives, conceptions, and understanding about English for Specific Purposes (ESP) courses with a focus on English for Nursing Purposes, and their motivations of learning English as a Foreign Language (EFL) as nursing students.

After the completion of both English for General Purposes (EGP) and English for Specific Purposes (ESP) courses, the instructors will contribute the survey to each student to fill out. This survey will only be contributed after the students completed both courses. For example, if the students completed English for General Purposes (EGP) first and the English for Specific Purposes (ESP) afterwards, the students should only complete the survey during the last lesson of the English for Specific Purposes (ESP) course, vice versa. After the researcher collected the survey back for data analysis, as the researcher tended to collect some interesting ideas and understand from the group's perspectives, the focus group activities were 
exercised.

First, the survey would be contributed to the students by the end of the whole course. The survey mainly asked students to share their ideas about motivations of learning, learning trends, and learning behaviours about English for Specific Purposes (ESP) and English as a Foreign Language (EFL) as nursing students at the university-level in South Korea. More importantly, the survey also tended to ask the ideas about the ideas, expectations and sharing between the English for General Purposes (EGP) and English for Specific Purposes (ESP) courses after the completion for both courses.

Second, after the survey procedures were completed, the researcher invited all 64 participants for an online-based interview session. The interview sessions focused on the ideas about English for General Purposes (EGP) courses and English for Specific (ESP) courses.

Third, after both procedures were completed, the researcher divided the participants into eight different focus groups (i.e. eight participants per group). The researcher released some ideas and questions to the group. The participants shared and expressed their ideas, sharing, lived stories, feeling, and understanding about their motivations of learning and learning trends of English for Specific Purposes (ESP) and English for Nursing Purposes (ENP) as nursing students at the university-level in South Korea. Each focus group activity lasted up to 124 minutes.

After all participants completed all the activities, the member checking procedures were conducted in order to confirm the information. The researcher categorised the information and sent the related part(s) to the participants for confirmation. All participants agreed on their own information for further report.

In fact, the native language (i.e. first language) of these participants was not English. Therefore, the researcher provided the opportunities to request an oral interpreter for immediate translation for both interview sessions and focus group activities. The cost of the translation services was charged to the researcher. However, none of the participants requested the service.

\subsection{Data Analysis}

After the data collection processes, more than 500 pages were categorised and grouped. In order to merge the information and sharing to meaningful themes and subthemes, the researcher employed the open-coding technique for the first-level themes and subthemes. As a result, 26 themes and 33 subthemes were merged. However, such large-size themes could not represent the overall performance of the sharing. Therefore, the researcher exercised the axial-coding technique to categorise the first-level themes to the second-level themes and subthemes [14], [36]. As a result, one theme and three subthemes were grouped for further development. For detail, please refer to Figure 1.

\subsection{Protection of Human Subjects}

Protecting the participants' personal information is one of the most important parts of this study. Therefore, the researcher exercised all procedures and tools for protection. The survey information, personal contacts, voice recording, video recording, singed agreements, transcripts, computer, and related materials were locked in the password-protected cabinet. Only the researcher has the key to access the information. After the study was completed, the researcher deleted and destroyed the related information immediately in order to protect the information from the participants.

All participants were given a pseudonym for the reporting as the personal identities of the participants do not take any roles for the study. No personal background information will be reported for the manuscript. Therefore, the participants were free to express their ideas and understanding during the survey information and focus group activities.

\section{Findings and Discussions}

One theme and three subthemes were merged for the study. As the study was focusing on two research questions, the themes for this study would answer the directions of the research questions.

Although all students are nursing students at the university-level in South Korea, the experiences, understanding, family background, expectation of foreign languages, and motivations of learning could be different from each other. The research needed to collect data and sharing from different tools in order to increase the validity and density of the findings. Table 1 outlined the themes and subthemes of this study.

\subsection{The English for Specific Purposes Courses are Applicable to Meet the Workplace Environment}

First of all, many participants admired the developments and designs of both English for General Purposes (EGP) and English for Specific Purposes (ESP) courses during their university voyage. Both courses might increase their English language knowledge and skills from different perspectives and directions. Several significant sharing was captured, said,

Both courses are excellent for university students...we can learn both daily conversations from the general English course, and we can learn nursing English from the targeted courses...I love both of the courses as we need these skills...

We are trained to become a professional, not just nurse in the future...it is good to have both English 
courses in order to increase our overall performance and skill...the courses focus on different perspective and idea...no one is better than others...

However, all participants strongly advocated that if possible, they would select English for Specific Purposes (ESP) courses with a focus of nursing English for their second language improvement.

\subsubsection{Both Courses are Applicable to Develop Different Skills of the Learners}

First of all, based on the sharing, all participants believed that both English for General Purposes (EGP) and English for Specific Purposes (ESP) courses are excellent tools for them to excel their language skills, proficiencies, and abilities for further development [9], [34]. First of all, a group of participants indicated that the English for General Purposes (EGP) courses increased their intercultural understanding between the Korean culture and foreign culture and expectations of their patients, one said,

I may need to exchange and express my general feeling and understanding to my friends...but just the environment in clinics and hospitals...the general English courses increased my capacities in this area... (Student \#44, Interview)

However, more importantly, all advocated that without the knowledge and understanding of the English for Specific Purposes (ESP) courses with a focus of nursing English, many cannot express and share essential public health information to their patients in the clinics and hospitals, one said,

...I did not understand or know how to conduct any walk-in sections from a clinical environment...It will be scare if you ask me to do in front of people...I don't know what to say and what should I collect...but after we watched the video and did a role-play with other classmates and teacher with the nursing elements...yes...I have the confidence to try ... a step forward (Student \#37, Interview Session)

In short, with the reflection of previous literature [5], [38]-[40], both English for General Purposes (EGP) courses and English for Specific Purposes (ESP) courses are designed for university students to understand four essential skills in foreign language learning. However, with the specific purposes for individual groups of students, in this case, nursing students, students are more likely to enjoy the teaching and learning materials (i.e. as the materials meet their expectations and career developments) [12].

\subsubsection{Application of the Public Health Facilities and Sites}

Instead of the English for General Purposes (EGP) courses, all participants would love to take the English for Specific Purposes (ESP) with a focus on nursing English for their academic and personal development. For example, in this case, many nursing students expected that their English for Nursing Purposes courses might upgrade their English language knowledge for the potential work environment and career development after completion [32]. It is worth noting that the if the school employed English textbooks with the nursing purposes and direction, the overall motivations of learning must be increased as the materials and lectures met their expectations and needs, as some said,

It is true that hospitals and clinics have different targets, patients, groups, specialisations, and ages etc...one random video from the textbook [English for General Purposes] cannot meet our needs...but the videos from our lessons [English for Specific Purposes] cover most of the clinics and hospital setting in our region...from general practitioners clinics to specialised departments...it is very rich and meaningful...(Student \#2, survey)

Some students also advocated that the English for Specific Purposes (ESP) with a focus on nursing English textbook and materials provided them the opportunities to understand the visual experiences between patients-public health professionals [38], one said,

As a fresh nursing student, I don't know anything about any hospital departments and management...but the videos from our teachers and this lesson cover a lot of departments and steps from our local clinics and hospitals...in fact, the Korean management and western management could not be the same...therefore, the current videos allow us to understand the real situation in Korea...(Student \#5, Interview)

In short, as all students were first-year and second-year nursing students, they should complete their general education and theoretical coursework before the internships and placements. Therefore, all agreed that although they cannot go to the hospitals, medical centres, and even local clinics in person, the English for Specific Purposes (ESP) courses with a focus on nursing English always increased their understanding, motivation, and interest in how to apply textbook knowledge in practice. With the reflection of previous literature [41], many advocated that the current foreign language teaching and learning strategies tended to be textbook-oriented, which they thought might limit students' imagination.

\subsubsection{Interdisciplinary Applications to other Subject Matters}

English language teaching and learning, and foreign language abilities are not the standalone skills and training for many university graduates, particularly nursing students who need to upgrade their vocational skills to the practical working environment after university graduation [11]-[13], [42]. According to a previous study [11], both pre-service and in-service nursing professionals need to 
understand and master different interdisciplinary skills and knowledge in order to meet the expectation and working requirement at the clinical level. For example, besides the knowledge, skills, training, and technical terms in their native language, in this case, the Korean language, the abilities and understanding of the English terms are essential (i.e. as nursing professionals need to work with international patients in both clinics and hospitals), two significant sharing was captured,

I think the English language teaching and learning should be employed to other subject matters in our programme as well...for example, the biology courses...I want to learn the names of our body parts in English...because in the future, I have to work with international patients... without the knowledge in English...how I can take to international patients... (Student \#31, Focus Group)

Because Korean is not useful at the international level...we have to learn Chinese, Arabic, English, or Russian in order to talk to international patients...therefore, if the foreign language courses...teaching and learning may cover other subject matters, such as physiology, biology, nursing sciences etc...students can excel their foreign language skills to the different level...(Student \#27, Interview)

With the reflection of previous literature [3], [10], [43], [44], English for Special Purposes (ESP) is not a new teaching approach and topic in foreign language teaching and learning. In this case, based on the nature of nursing education and nursing English, the researcher liked to investigate how these English for Special Purposes and English for Nursing Purposes might increase the motivations of learning for nursing students in South Korea. In the reflection of a previous study [10], [39], [44], students with special expectations and purposes tend to expect targeted knowledge and results from their lessons and courses. In this case, all 64 students indicated that one of the most important elements and motivations for them to learn English as a Foreign Language is career development. As a result, many students have their own thinking and arrangements for their future and learning directions.

\section{Limitations and Future Research Developments}

\subsection{Limitations}

Every study has its limitations. Two limitations were concluded for this study. First, due to the number of students in this study, the results might only apply to a small group of undergraduate nursing students. Although youths' behaviour and interests may be similar, students from different academic programmes and majors may have different learning behaviours and ways. For example, students from the evening programmes and liberal arts courses may not have the same ideas and ways of learning as undergraduate nursing students with the science-oriented background. Therefore, the results of this pilot study might only be relevant to the behaviour of undergraduate nursing students. Also, the participants in this study were traditional-age students; non-traditional, returning, evening, adult (NTREA) students' behaviour could be different, therefore producing different results [45], [46].

Second, some scholars may argue the research method is not enough to cover the data information and results from the participants. However, in order to increase the validity of the results, the researcher employed surveys, interview sessions and focus group activities for data collection. Under this arrangement, the results may cover and collect a wider range of data from the students.

\subsection{Future Research Developments}

There are four recommendations for future research directions. First, the research population can be expanded to students in other academic departments. For this study, the surveys, interview sessions and focus group activities could only cover nursing undergraduate students. Therefore, there is a need to understand the English for General Purposes (EGP) courses and English for Specific Purposes (ESP) courses could be beneficial to other students with a different background. More importantly, how other groups of students would describe their experiences.

Second, the student populations of this study had intermediate to advanced levels of English language proficiency. However, if these study methodologies were to be applied to pre-level or beginner-level learners, the results could be different due to the difference in language proficiency. Therefore, there is a need to understand the effectiveness of using such an approach with students of different language levels.

Third, nursing students understand language proficiency is the key for them to access potential career development after graduation. Therefore, many of them have positive learning motivation before this English course. It is not hard to understand that they like to learn and practice. However, for students with less motivation, the results can be different. Therefore, there is a need to understand students with less motivation and interest in learning the English language at college or university level.

Fourth, this study only tested English language courses. However, different subjects and courses, such as Chinese Mandarin, Nursing Practices, general studies, writing courses, and so on, may produce different results. 


Step 1 - Transcribe all the voice records into written transcripts.
- Read the transcripts several times in order to gather meaningful data information
Step 2 - Aategorise the data information into groups and themes based on the purpose of the study.
Apporach.
Step 33 - Start to code the large-size data information into categories and themes.
- Open-coding technique.
- Start to code first-level themes into narrowed categories and themes.
- One theme and three subthemes.
- Axial-coding technique.

Figure 1. Data Analysis Procedure

\section{Conclusions}

The results of this study indicated that a large number of students, particularly nursing students in the South Korean nursing school environment, prefer the English for Specific Purposes (ESP) courses. First, many indicated that the English for Specific Purposes (ESP) courses are applicable to meet the workplace environment. Second, the applications and knowledge of English for Specific Purposes (ESP) courses may further apply to their future career developments and internship opportunities. Third, the applications, skills, and knowledge from the English for Specific Purposes (ESP) courses can further apply to different academic subjects and courses as they can build up the knowledge from various perspectives. The results of this study may provide a blueprint for school leaders, department heads, policymakers, government officials, and researchers to reform and polish their foreign language policies and professional developments for both pre-service [18-19] and in-service medical professionals $[16]$ in the East Asian region.

Table 1. Themes and Subthemes

\begin{tabular}{|l|l|l|}
\hline \multicolumn{3}{|c|}{ Themes and Subthemes } \\
\hline 3.1. & & $\begin{array}{l}\text { The English for Specific Purposes Courses are } \\
\text { Applicable to Meet the Workplace Environment }\end{array}$ \\
\hline & 3.1 .1$. & $\begin{array}{l}\text { Both Courses are Applicable to Develop different } \\
\text { Skills of the Learners }\end{array}$ \\
\hline & 3.1 .2$. & Application of the Public Health Facilities and Sites \\
\hline & 3.1 .3$. & $\begin{array}{l}\text { Interdisciplinary Applications to other Subject } \\
\text { Matters }\end{array}$ \\
\hline
\end{tabular}

\section{Acknowledgments}

The study was supported by Woosong University
Academic Research Funding 2020.

\section{REFERENCES}

[1] A. Howatt and H. G. Widdowson, A History of English Language Teaching, 2rd ed. Oxford, UK: Oxford University Press, 2004.

[2] J. Harmer, The practice of English language teaching. Essex, UK: Pearson, 1988.

[3] A. Johns and T. Dudley-Evans, "English for specific purposes: International in scope, specific in purpose," TESOL Q., vol. 25, no. 2, p. 297, 1991, doi: $10.2307 / 3587465$.

[4] S. Dennaoui, K.; Nichills, R.; O’Connor, M.; Tarasuik, J.; Kvalsvig, A.; Goldfeld, "The English proficiency and academic language skills of Australian bilingual children during the primary school years," Int. J. Speech. Lang. Pathol., vol. 18, no. 2, pp. 157-165, 2016, doi: 10.3109/17549507.2015.1060526.

[5] B. Džuganová, "Teaching medical English through professional captioning videos," J. Lang. Cult. Educ., vol. 7, no. 2, pp. 95-107, Sep. 2019, doi: 10.2478/jolace-2019-001 3.

[6] D. Nunan, Teaching English to Speakers of Other Languages. New York, NY: Routledge, 2015.

[7] W. Grabe and R. Kaplan, Theory and practice of writing: An applied linguistic perspective. New York, NY: Routledge, 1996.

[8] L. M. Dos Santos, "English as a foreign language textbook for engineering students: Application of the Dos Santos' textbook material evaluation checklist," J. Eng. Appl. Sci., vol. 14 , no. 22 , pp. 8415-8419, 2019. 
[9] L. M. Dos Santos, "Evaluation checklist for English language teaching and learning for health science professionals," World Trans. Eng. Technol. Educ., vol. 17, no. 4, pp. 431-436, 2019.

[10] T. Hutchinson and A. Waters, English for specific purposes. Cambridge, UK: Cambridge University Press, 1987.

[11] P. A. Ali and S. Johnson, "Speaking my patient's language: bilingual nurses' perspective about provision of language concordant care to patients with limited English proficiency," J. Adv. Nurs., vol. 73, no. 2, pp. 421-432, Feb. 2017, doi: 10.1111/jan.13143.

[12] K. King, C. Porr, and A. Gaudine, "Fostering academic success among English as an additional language nursing students using standardized patients," Clin. Simul. Nurs., vol. 13, no. 10, pp. 524-530, Oct. 2017, doi: 10.1016/j.ecns.2017.06.001.

[13] M. G. Tweedie and R. C. Johnson, "Listening instruction for ESP: Exploring nursing education where English is a lingua franca," in International Perspectives on Teaching the Four Skills in ELT, Cham: Springer International Publishing, 2018, pp. 65-77.

[14] S. B. Merriam, Qualitative research: A guide to design and implementation. San Francisco, CA: Jossey Bass, 2009.

[15] K. H. Tang and L. M. Dos Santos, "A brief discussion and application of interpretative phenomenological analysis in the field of health science and public health," Int. J. Learn. Dev., vol. 7, no. 3, pp. 123-132, Aug. 2017, doi: 10.5296/ijld.v7i3.11494.

[16] L. M. Dos Santos, "The relationship between the COVID-19 Pandemic and nursing students' sense of belonging: The experiences and nursing education management of pre-Service nursing professionals," Int. J. Environ. Res. Public Health, vol. 17, no. 16, p. 5848, Aug. 2020, doi: 10.3390/ijerph17165848.

[17] L. M. Dos Santos, "Pre-service teachers' professional development through four-step problem-solving model: A seminar method," Int. J. Educ. Pract., vol. 7, no. 3, pp. 146157, 2019, doi: 10.18488/journal.61.2019.73.146.157.

[18] H. A. McCarty M, "Moving to an all graduate profession: preparing preceptors for their role.," Nurse Educ. Today, vol. 23 , no. 2, pp. 89-95, 2003.

[19] M. Jones, "Career Commitment of Nurse Faculty," Res. Theory Nurs. Pract., vol. 31, no. 4, pp. 364-378, Jan. 2017, doi: 10.1891/1541-6577.31.4.364.

[20] M. Seth, Education fever: Society, politics, and the pursuit of schooling in South Korea. Honolulu, HI: University of Hawai'i Press, 2002.

[21] F. L. Collins and S. Shubin, "Migrant times beyond the life course: The temporalities of foreign English teachers in South Korea," Geoforum, vol. 62, no. 1, pp. 96-104, Jun. 2015, doi: 10.1016/j.geoforum.2015.04.002.

[22] S. A. DeWaelsche, "Critical thinking, questioning and student engagement in Korean university English courses," Linguist. Educ., vol. 32, pp. 131-147, Dec. 2015, doi: 10.1016/j.linged.2015.10.003.

[23] L. M. Dos Santos, “The cultural cognitive development of personal beliefs and classroom behaviours of adult language instructors: A qualitative inquiry," Brain Sci., vol. 8, no. 12, p. 220, Dec. 2018 , doi: 10.3390/brainsci8120220.

[24] S. Im, H.-G. Yoon, and J. Cha, "Pre-service Science Teacher Education System in South Korea: Prospects and Challenges," EURASIA J. Math. Sci. Technol. Educ., vol. 12, no. 7, pp. 1863-1880, Jul. 2016, doi:10.12973/eurasia.2016 $.1533 \mathrm{a}$.

[25] T. Taguchi, M. Magid, and M. Papi, "The 12 motivational self system among Japanese, Chinese and Iranian learners of English: A comparative study," in Motivation, language identity and the L2 self, Z. Dornyei and E. Ushioda, Eds. Bristol, UK: Multilingual Matters, 2009, pp. 66-97.

[26] M. Gagné and E. L. Deci, "Self-determination theory and work motivation," J. Organ. Behav., vol. 26, no. 4, pp. 331362, Jun. 2005, doi: 10.1002/job.322.

[27] M. Gilboy, S. Heinerichs, and G. Pazzaglia, "Enhancing student engagement using the flipped classroom," J. Nutr. Educ. Behav., vol. 47, no. 1, pp. 109-114, Jan. 2015, doi: 10.1016/j.jneb.2014.08.008.

[28] C. M. Critz and D. Knight, "Using the flipped classroom in graduate nursing education," Nurse Educ., vol. 38, no. 5, pp. 210-213, 2013, doi: 10.1097/NNE.0b013e3182a0e56a.

[29] R. C. F. Sun, “Teachers' experiences of effective strategies for managing classroom misbehavior in Hong Kong," Teach. Teach. Educ., vol. 46, pp. 94-103, Feb. 2015, doi: 10.1016/j.tate.2014.11.005.

[30] L. M. Dos Santos, "Textbook evaluation in the field engineering and applied sciences: A development and application for the use of university-level textbook," J. Eng. Appl. Sci., vol. 14, no. 13, pp. 4603-4606, 2019.

[31] M. Ahmed, H. Yaqoob, and M. Yaqoob, "Evaluation of listening skill of ELT textbook at secondary school level," Adv. Lang. Lit. Stud., vol. 6, no. 3, pp. 225-229, 2015.

[32] L. M. Dos Santos, "Evaluation of the appropriateness of nursing teaching and learning materials: The application of textbook evaluation," J. Eng. Appl. Sci., vol. 14, no. 23, pp. 8817-8822, 2019.

[33] N. Chegeni, B. Kamali, A. Noroozi, and N. Chegeni, "General English textbook evaluation: A closer look at 'Four Corners,"” Theory Pract. Lang. Stud., vol. 6, no. 12, p. 2325, Dec. 2016, doi: 10.17507/tpls.0612.13.

[34] L. M. Dos Santos, "English language learning for engineering students: Application of a visual-only video teaching strategy," Glob. J. Eng. Educ., vol. 21, no. 1, pp. 37-44, 2019.

[35] L. M. Dos Santos, "Science lessons for non-science university undergraduate students: An application of visual-only video teaching strategy," J. Eng. Appl. Sci., vol. 14, no. 1, pp. 308-311, 2019.

[36] J. Creswell, Research design: Qualitative, quantitative, and mixed methods appraoches, 4th ed. Thousand Oaks, CA: Sage, 2014.

[37] D. R. Thomas, “A general inductive approach for analyzing qualitative evaluation data," Am. J. Eval., vol. 27, no. 2, pp. 237-246, Jun. 2006, doi: 10.1177/1098214005283748. 
[38] L. M. Dos Santos, "Employing a technologically-assisted teaching and learning strategy in the English as a foreign language classroom: The application of the visual-only video teaching strategy," in International Conference on Open and Innovative Education, 2020, pp. 143-156.

[39] J. Day and M. Krzanowski, English for specific purposes: An introduction. Cambridge, UK: Cambridge University Press, 2010.

[40] D. W. Cho, "English-medium instruction in the university context of Korea: Tradeoff between teaching outcomes and media-initiated university ranking," J. Asia TEFL, vol. 9, no. 4, pp. 153-163, 2012.

[41] E. Wilson, A. Chen, K. Grumbach, F. Wang, and A. Fernandez, "Effects of limited English proficiency and physician language on health care comprehension," J. Gen. Intern. Med., vol. 20, no. 9, pp. 800-806, Sep. 2005, doi: 10.1111/j.1525-1497.2005.0174.x.

[42] P. J. Glew, S. P. Hillege, Y. Salamonson, K. Dixon, A. Good, and L. Lombardo, "Predictive validity of the post-enrolment English language assessment tool for commencing undergraduate nursing students," Nurse Educ. Today, vol. 35, no. 12 , pp. 1142-1147, Dec. 2015, doi: 10.1016/j.nedt.2015.04.012.

[43] J. (Tracy) Tao and X. (Andy) Gao, "Identity constructions of ESP teachers in a Chinese university," English Specif. Purp., vol. 49, pp. 1-13, Jan. 2018, doi: 10.1016/j.esp.2017.09.003.

[44] S. Evans and B. Morrison, "Meeting the challenges of English-medium higher education: The first-year experience in Hong Kong," English Specif. Purp., vol. 30, no. 3, pp. 198-208, Jul. 2011, doi: 10.1016/j.esp.2011.01.001.

[45] L. M. Dos Santos, "I want to become a registered nurse as a non-traditional, returning, evening, and adult student in a community college: A study of career-changing nursing students," Int. J. Environ. Res. Public Health, vol. 17, no. 16, p. 5652, Aug. 2020, doi: 10.3390/ijerph17165652.

[46] L. M. Dos Santos, "The motivation and experience of distance learning engineering programmes students: A study of non-traditional, returning, evening, and adult students," Int. J. Educ. Pract., vol. 8, no. 1, pp. 134-148, 2020, doi: 10.18488/journal.61.2020.81.134.148. 